See discussions, stats, and author profiles for this publication at: https://www.researchgate.net/publication/327631445

\title{
Pengantar Manajemen
}

Book · September 2018

CITATIONS

2 authors:

Dedy Ansari Harahap

Universitas Islam Sumatera Utara

13 PUBLICATIONS 6 CITATIONS

SEE PROFILE
READS

26

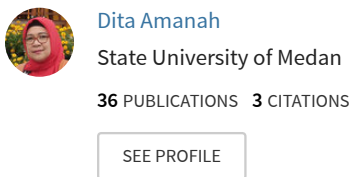

Some of the authors of this publication are also working on these related projects:

ANALISIS SIKAP PENGGUNA JASA LAYANAN PERPUSTAKAAN KELILING BADAN ARSIP DAN DOKUMENTASI DAERAH PROVINSI SUMATERA UTARA VIEW PROJECT 


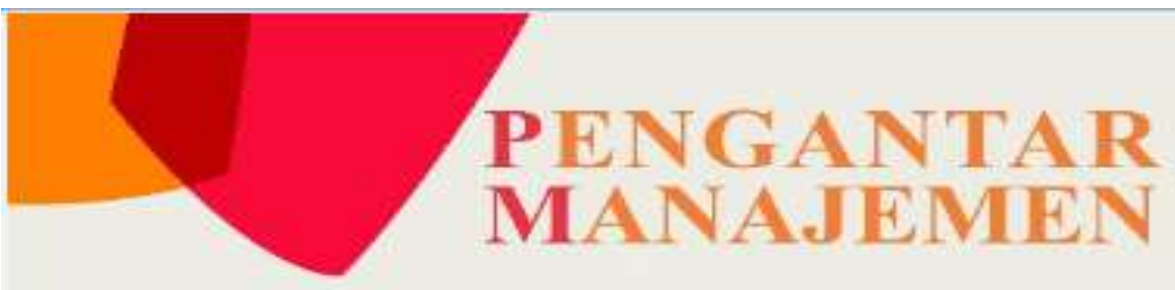

Buku Pengantar Mahajemen ini cidesain untuk mersperkenalkan mahasiswa tentang manajemen dalam buku l'engantar Manajemen yang didukung bertagai teori dan pendapat ahli, serta rujukan bagi dosen pengampu mata kuliah Pengantar Manajerneo. Selain itu di ngkasan, pertanyzan dan glosatum. Bukt ini diharapkan menjadi rujckan pada mata kuliah Pcrigantar Manaymen yang terdiri darl seputun bab yairu Dasar-dasar Manajemen, Sejarah dan Teori Manijemen, Manajemen dan

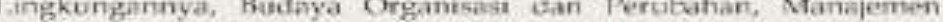
Strategik, Tenganbian keputasan, Manajenten Samberdaya Manusia, Motivast, Kepemimpinan dan Komtanikisit.

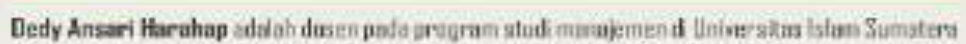

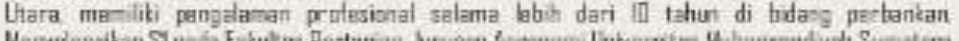

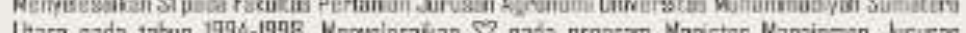

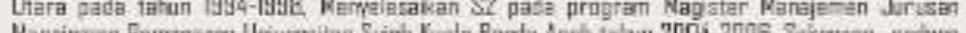

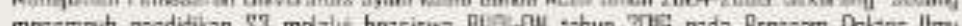

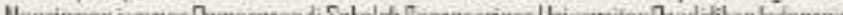
Dita Amanah addiah tasan jususen manjiemen pemasaran a Universitas Kegeri Kotan Sumatera

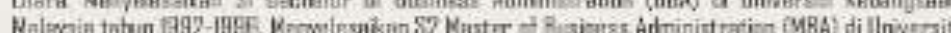

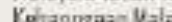

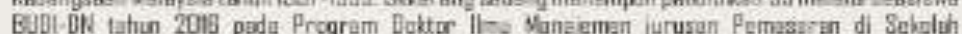

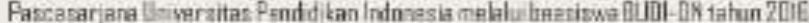

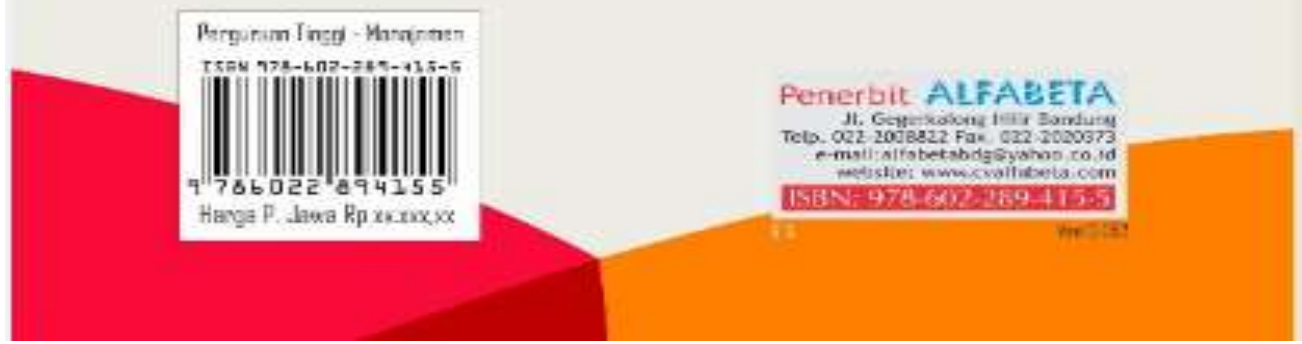

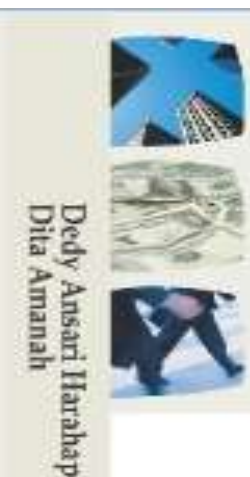

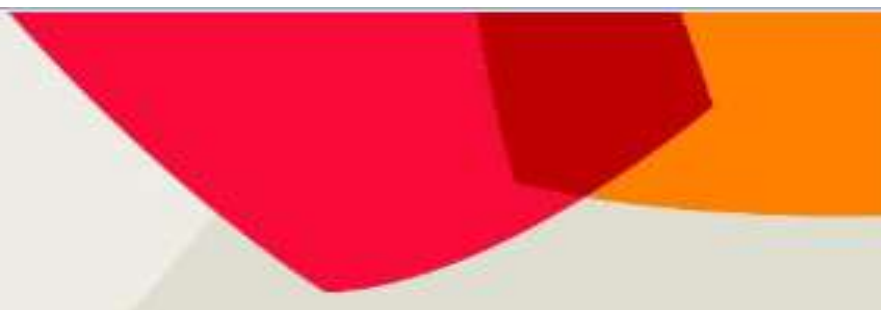

Dedy Ansari Harahap Dita Amanah

\section{PENGANTAR MANAJEMEN

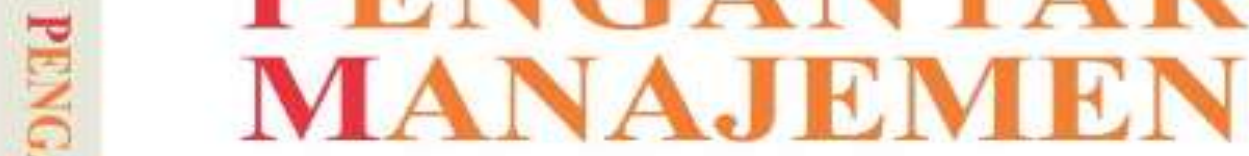

98.

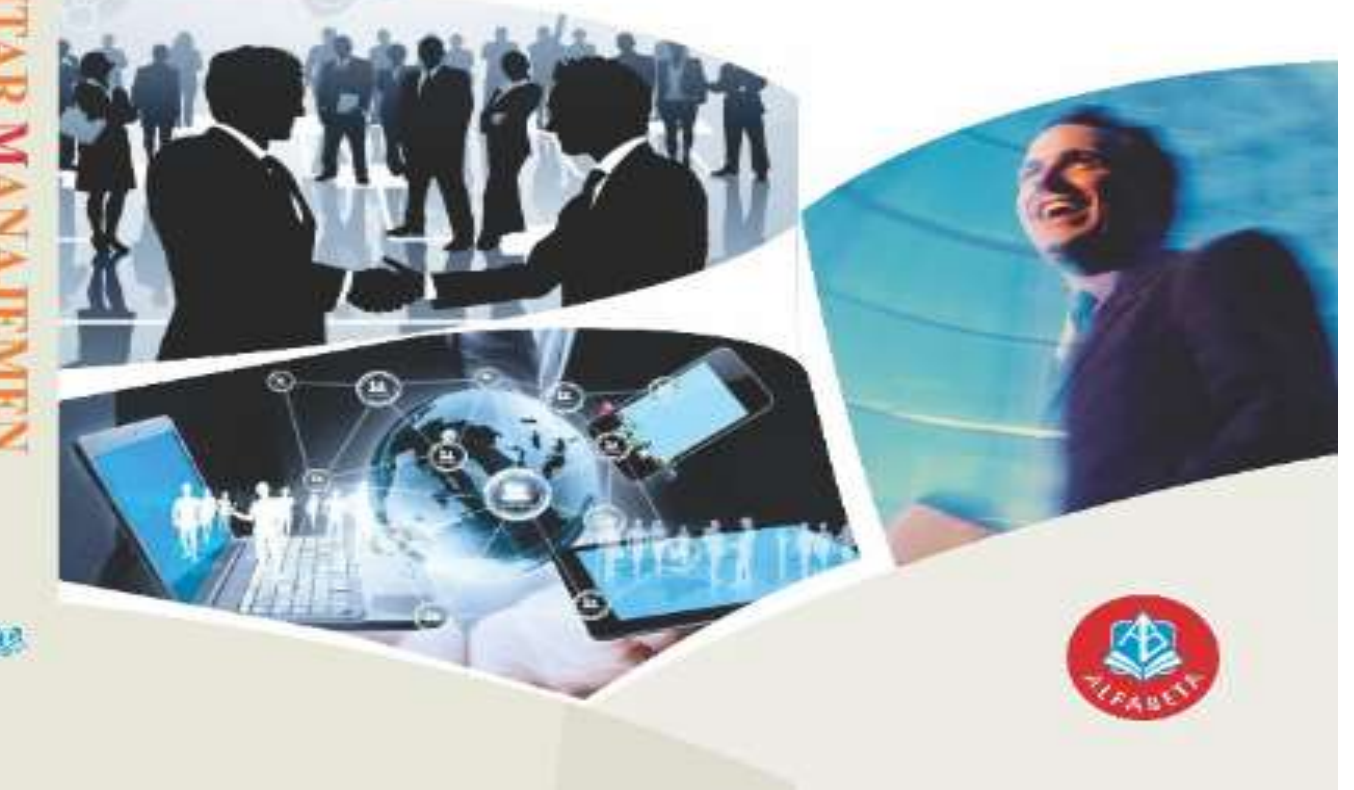




\section{KATA PENGANTAR}

Segala puji bagi Allah, yang telah memberikan kenikmatan, hidayah, taufik dan inayah-Nya sehingga penulis dapat menyelesaikan penulisan buku ini. Sholawat beriring salam saya persembahkan kepada junjungan Nabi Besar Muhammad SAW, semoga kita mendapatkan syafaatnya di yaumil akhir. Aamiin Yaa Robbal Alamin.

Buku ini disusun dengan harapan dapat digunakan untuk mahasiswa dan dosen, khususnya bagi mahasiswa yang mengambil mata kuliah pengantar manajemen dan utamanya bagi dosen yang mengampu mata kuliah pengantar manajemen. Efektifitas sebuah buku yang akan dipelajari bagi masyarakat umum, manajer, mahasiswa dan dosen dan tidak berlebihan namun ringkas dan praktis sehingga memudahkan bagi pembaca dalam mempelajari manajemen. Banyak orang dengan mudah merangkai istilah manajemen dengan permasalahan yang akan dipecahkan sehingga menimbulkan banyak makna dan esensi dasar manajemen itu sendiri. Oleh karena itu, dalam buku ini diyakini bahwa para pembaca akan memahami karakteristik ilmu dan seni manajemen secara mendasar.

Penulis mencoba menunjukkan kepada pembaca secara terstruktur dasar manajemen, sejarah dan teori manajemen sehingga memudahkan pembaca memahami dan mengerti tentang manajemen. Tidak hanya dalam bentuk kalimat-kalimat, pendapat dari para ahli manajemen serta penulis juga menjelaskan berbagai hal mengenai manajemen dengan berbagai gambar dan tabel.

Buku ini secara khusus ditujukan untuk mahasiswa, dosen, manajer dan masyarakat umum. Diharapkan dapat membantu mahasiswa dalam mengikuti mata kuliah Pengantar Manajemen, bagi dosen pengampu mata kuliah Pengantar Manajemen dan bagi mamajer maupun masyarakat memahami sumberdaya manusia, organisasi, kepemimpinan, motivasi dan komunikasi.

Penulis ucapkan banyak terima kasih pada berbagai pihak yang membantu dalam pembuatan buku ini. Penulis menyadari bahwa dalam buku ini masih jauh dari sempurna serta banyak kelemahan dan kesalahan. Semua tak terlepas dari keterbatasan pengetahuan serta pengalaman. Untuk itu penulis sangat menghargai kritik dan saran pembaca atas perbaikan buku ini. Atas segala kesalahan dan kelemahan buku ini kami 
memohon maaf sebesar-besarnya, semoga dalam penerbitan buku selanjutnya dapat dibuat lebih sempurna.

Bandung, 20 Februari 2018

Penulis 


\section{DAFTAR ISI}

KATA PENGANTAR
DAFTAR ISI
DAFTAR GAMBAR
DAFTAR TABEL
BAB 1 DASAR-DASAR MANAJEMEN

Halaman

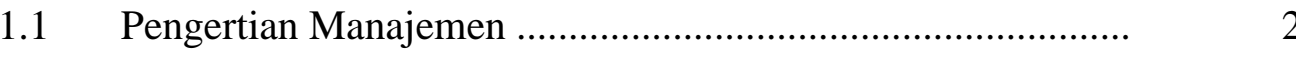

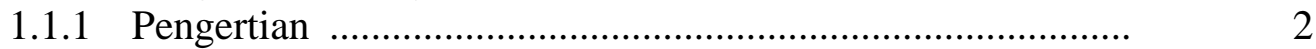

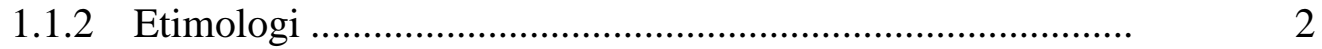

1.1.3 Pengertian dan Batasan Manajemen .................................... 2

$1.2 \quad$ Fungsi dan Proses Manajemen ................................................ 3

1.3 Sarana Manajemen............................................................. 4

$1.4 \quad$ Prinsip Manajemen ............................................................. 5

1.5 Piramida Kekuasaan dan Jenjang Manajemen........................ 5

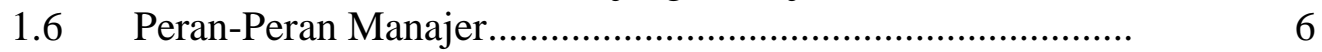

$\begin{array}{lll}1.7 & \text { Keterampilan (Skill) Yang Dituntut Bagi Seorang Manajer.. } & 7\end{array}$

$1.8 \quad$ Bidang-Bidang Manajemen .................................................

1.9 Proses Manajemen Indonesia................................................. 9

1.10 Birokrasi dalam Organisasi Indonesia ................................... 10

$\begin{array}{lll}1.11 & \text { Perilaku Manusia Indonesia dalam Organisasi Manajemen .. } & 11\end{array}$

1.12 Faktor Budaya dalam Organisasi dan Manajemen Indonesia 12

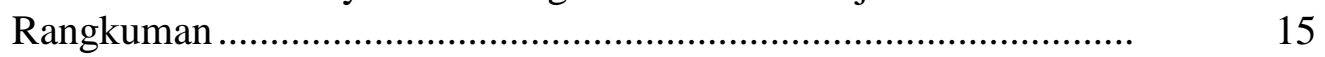

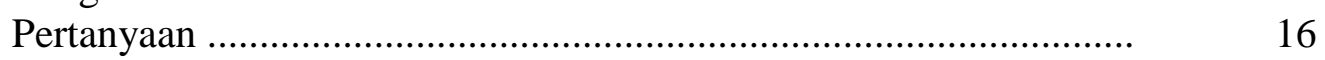

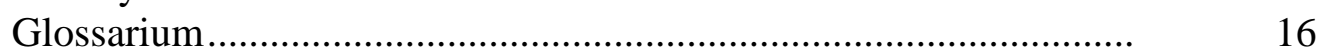

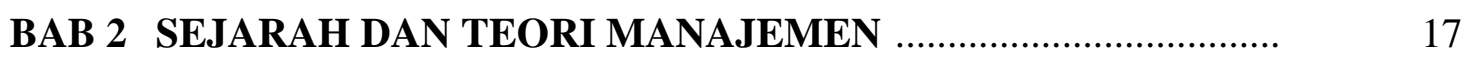

$2.1 \quad$ Sejarah Manajemen.......................................................... 18

2.1.1 Pra Manajemen Ilmiah ..................................................... 18

2.1.2 Revolusi Industri.......................................................... 18

2.2 Perkembangan Ilmu Manajemen ........................................... 19

2.3 Teori Manajemen ............................................................. 20

2.4 Kelompok Pemikiran dalam Ilmu Manajemen ........................ 20

2.4.1 Manajemen Klasik ............................................................... 20

2.4.1.1 Manajemen Ilmiah atau Saintifik....................................... 21

2.4.1.2 Teori Organisasi Klasik ...................................................... 23

2.4.2 Manajemen Hubungan Manusiawi ...................................... 27

2.4.3 Manajemen Modern ........................................................... $\quad 30$

2.4.3.1 Perilaku Organisasi .......................................................... $\quad 30$

2.4.3.2 Manajemen Kuantitatif ..................................................... $\quad 30$

2.5 Teori Manajemen Kontemporer............................................. 31

2.5.1 Pendekatan Sistem .......................................................... 31

2.5.2 Pendekatan Kontingensi .................................................... 32

2.6 Beberapa isu-isu Kontemporer Seputar Perkembangan

Rangkuman ....................................................................... 34

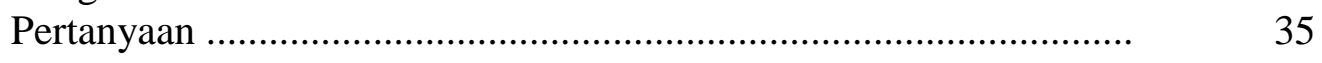

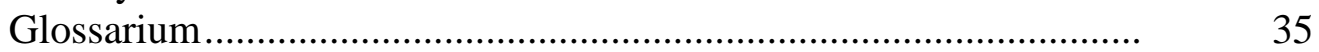


BAB 3 MANAJEMEN DAN LINGKUNGANNYA ............................. 36

3.1 Lingkungan Eksternal Perusahaan ......................................... 37

3.1.1 Pendekatan Ekonomi Industri ............................................... 37

3.1.2 Pendekatan Kekuatan Persaingan Porter ............................ 38

3.1.3 Meramalkan Kondisi Ekternal Masa Depan ........................ $\quad 40$

3.2 Lingkungan Umum dan Khusus Perusahaan ....................... 42

3.3 Lingkungan Internal Perusahaan .......................................... 42

3.3.1 Proses Analisis Lingkungan Internal ................................ 43

3.3.2 Pendekatan dalam Mengidentifikasi Variabel Internal........... 43

3.3.3 Pendekatan Dalam Mengevaluasi Variabel Internal.............. 46

3.3.4 Anaalisis Internal Untuk Menciptakan

Sustainable Competitive Advantage .................................... 46

3.4 Hubungan Lingkungan dan Organisasi............................... 47

3.4.1 Usaha Mempengaruhi Lingkungan Eksternal Mikro............. 48

3.4.2 Peramalan (Forecasting) dan Lingkungan Eksternal Makro.. $\quad 48$

Rangkuman ..................................................................... $\quad 50$

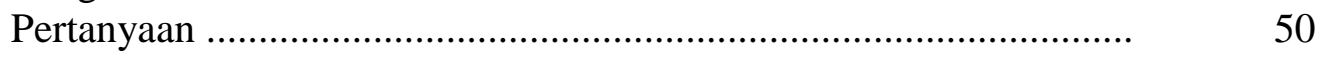

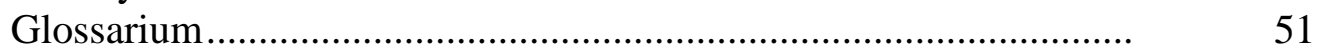

BAB 4 BUDAYA ORGANISASI DAN PERUBAHAN ....................... 52

$4.1 \quad$ Budaya Organisasi ............................................................... 53

4.2 Elemen Budaya Organisasi ................................................. 61

4.3 Proses Terbentuknya Budaya Organisasi …........................ 63

4.4 Budaya Organisasi : Aktiva dan Kewajiban .......................... 65

4.5 Penghalang Budaya Organisasi ........................................... 66

4.6 Resistensi Perubahan .......................................................... 68

4.7 Perubahan Organisasi dan Isu Kepemimpinan Transformasional 72

4.8 Isu Organisasi Pembelajaran Dalam Konteks

Perubahan Organisasi ......................................................... $\quad 74$

4.9 Peran Sistem Pembelajaran Dalam Proses Perubahan........... 77

4.10 Peran Kepemimpinan Transformasional Dalam Mensukseskan Perubahan Organisasi .................................... $\quad 79$

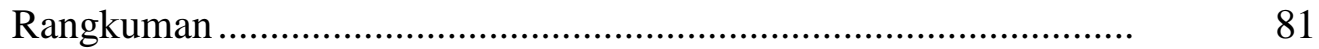

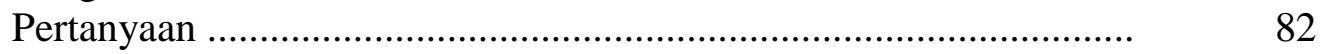

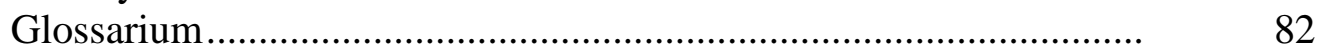

BAB 5 MANAJEMEN STRATEGIK ….......................................... 83

$5.1 \quad$ Strategik .................................................................. 84

$5.2 \quad$ Pengertian Strategik ...................................................... 86

5.3 Pengertian Manajemen Strategik ...................................... 87

5.4 Manfaat Manajemen Strategik ........................................... 88

5.5 Ciri-Ciri Proses Manajemen Strategik ................................ 89

5.6 Model Manajemen Strategik.............................................. 89

5.7 Proses Manajemen Strategik .................................................. 93

5.8 Teknik-teknik untuk menganalisis keputusan strategik .......... 94

Rangkuman .............................................................................. 96

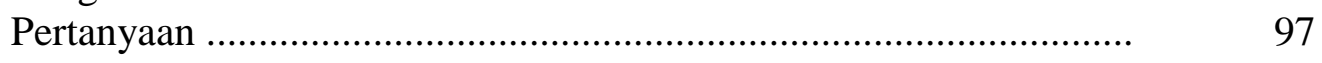

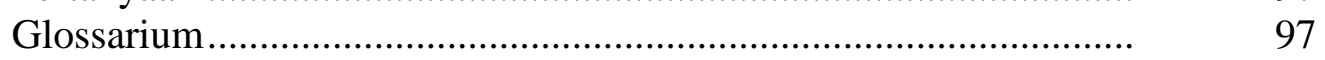

BAB 6 PENGAMBILAN KEPUTUSAN …...................................... 98

6.1 Dasar-Dasar Pembuatan Keputusan.................................... 99 
6.2 Jenis-Jenis Keputusan ........................................................ 99

6.3 Pertanggungjawaban bagi pembuatan keputusan organisasi . $\quad 100$

6.4 Unsur-unsur situasi atau keadaan keputusan ......................... 100

6.4.1 Tujuan-Tujuan Yang Harus Dicapai .................................... 101

6.5 Proses Pembuatan Keputusan ............................................. 101

6.6 Kondisi Pembuatan Keputusan .......................................... 103

6.7 Perangkat-Perangkat dalam Pembuatan Keputusan ............... 104

Rangkuman ........................................................................ 105

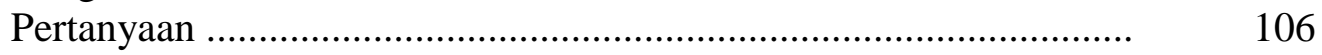

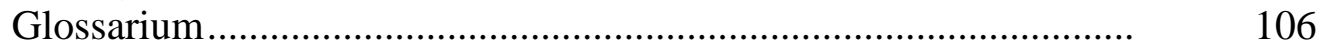

BAB 7 MANAJEMEN SUMBERDAYA MANUSIA ….......................... 108

7.1 Pendahuluan............................................................... 108

7.2 Pengertian MSDM ............................................................... 108

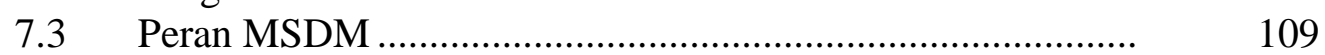

7.4 Model MSDM................................................................. 110

7.5 Prinsip-Prinsip Pengelolaan MSDM................................... 111

7.6 Fungsi dan Peran MSDM .................................................. 112

7.7 Fungsi Operasional MSDM ............................................. 114

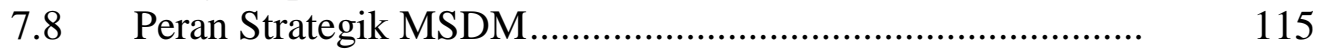

7.9 Paradigma Lama MSDM .................................................... 116

7.10 Paradigma Baru MSDM ...................................................... 117

7.11 Manfaat Penerapan MSDM ................................................. 118

7.12 Tantangan MSDM ............................................................... 118

7.13 Peran MSDM untuk meraih keunggulan kompetitif............... 120

Rangkuman ............................................................................. 121

Pertanyaan ............................................................................ 122

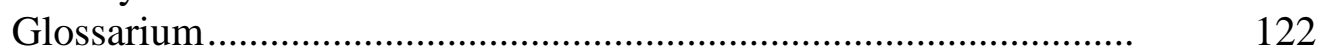

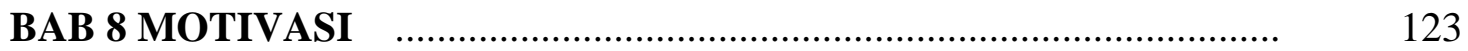

8.1 Pengertian Motivasi .............................................................. 124

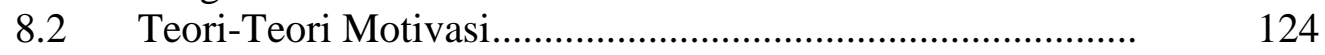

8.2.1 Motivasi Individu................................................................ 124

8.2.2 Jenis dan Bentuk Motivasi .................................................... 128

8.3 Hubungan Desain Pekerjaan dengan Motivasi ..................... 136

8.4 Hubungan Motivasi dengan Sistem Upah ............................ 140

8.5 Sistem Balas Jasa yang Efektif untuk Memotivasi Pekerja... 142

8.6 Pengembangan Insentif dalam Memotivasi Pekerja ............... 147

Rangkuman ............................................................................ 149

Pertanyaan ....................................................................... 150

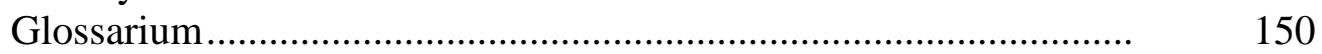

BAB 9 KEPEMIMPINAN ............................................................ 151

9.1 Pendahuluan ................................................................... 153

9.2 Pengertian Kepemimpinan...................................................... 153

9.3 Teori Kepemimpinan ............................................................ 153

9.4 Kepemimpinan Formal dan Informal .................................... 154

9.5 Tipe Kepemimpinan ...................................................... 155

9.6 Etika Kepemimpinan .......................................................... 156

9.7 Kepemimpinan Spiritual Tanpa Agama ............................. 157

9.8 Kepemimpinan Spiritual Berdasarkan Agama 
Kepemimpinan dalam Islam ............................................ $\quad 158$

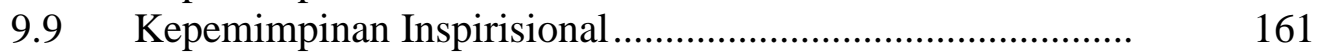

9.10 Memimpin Diri Sendiri.................................................. 165

9.11 Isu-isu Kontemporer Kepemimpinan................................. 166

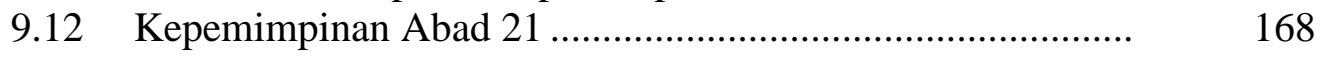

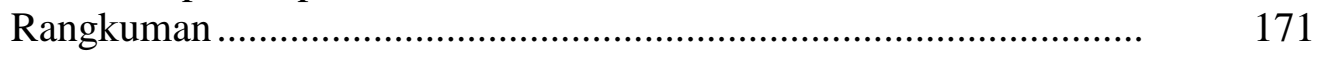

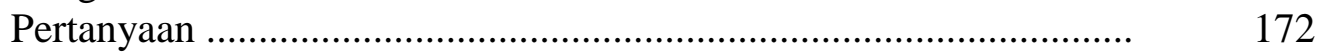

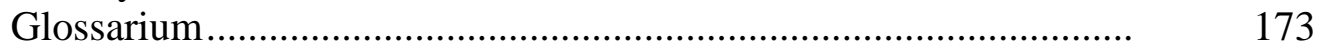

BAB 10 KOMUNIKASI ............................................................. 174

10.1 Pengertian Komunikasi ........................................................ 175

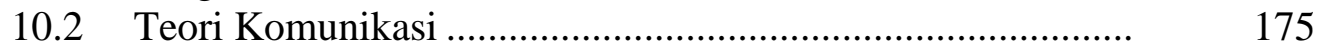

10.3 Fungsi Komunikasi ......................................................... 181

10.4 Jenis Komunikasi ........................................................ 184

10.5 Proses Komunikasi ..................................................... 185

10.6 Model-Model Komunikasi.................................................. 186

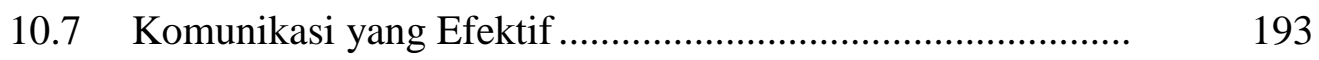

10.8 Komunikasi dalam Organisasi .............................................. 193

10.9 Teori Komunikasi Organisasi ............................................ 196

10.10 Fungsi Komunikasi dalam Organisasi ................................ 198

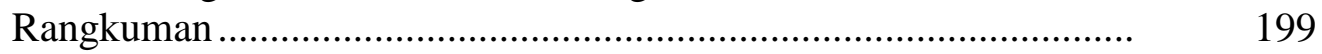

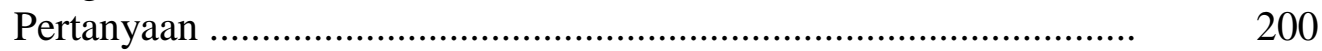

Glossarium ....................................................................... 200

DAFTAR PUSTAKA ….............................................................. 201 


\section{DAFTAR GAMBAR}

Halaman

Gambar 1.1 Bagan Fungsi Manajemen................................................. 3

Gambar 1.2 Piramida Jenjang Manajemen............................................... 6

Gambar 2.1 Perspektif sistem dalam manajemen...................................... 31

Gambar 3.1 Lima kekuatan kompetisi Michael Porter keunggulan kompetitif 38

Gambar 3.2 Perbandingan Forecast dan Scenario .................................... $\quad 40$

Gambar 3.3 Mental Map of Reality ...................................................... 41

Gambar 3.4 Rantai Nilai ....................................................................... 45

Gambar 4.1 Bagaimana Budaya Organisasi Dibentuk .............................. 56

Gambar 4.2 Tiga Tingkatan Budaya Organisasi........................................ 5

Gambar 4.3 Dimensi-dimensi Budaya Organisasi................................... $\quad 59$

Gambar 4.4 Model Budaya Pembelajaran Terpadu...................................... 61

Gambar 4.5 Proses Terbentuknya Budaya Organisasi.............................. 64

Gambar 4.6 Model Tiga Langkah Perubahan Lewins............................... 67

Gambar 4.7 Sumber-sumber Resistensi Individu untuk Perubahan ............ 69

Gambar 4.8 Pembelajaran Organisasi yang Efektif Mampu

Mempengaruhi Penghambat Pembalajaran........................... $\quad 78$

Gambar 5.1 Piramida Strategi................................................................ 84

Gambar 5.2 Model Manajemen Strategik ..................................................... 91

Gambar 5.3 Model Manajemen Strategik Micheal A. Hitt ........................ 92

Gambar 5.4 Model Manajemen Strategik Robinson .................................. $\quad 92$

Gambar 5.5 Model Manajemen Strategi Pearce \& Robinson.......................

Gambar 8.1 Tingkatan kebutuhan seseorang menurut Maslow................... 125

Gambar 8.2 Teori Harapan dalam Motivasi Pekerja .................................. 131

Gambar 8.3 Tanggung jawab manajer dalam memotivasi pekerja.............. 133

Gambar 10.1 Model Proses Komunikasi ..................................................... $\quad 186$

Gambar 10.2 Model Komunikasi Lasswell .................................................. 187

Gambar 10.3 Model Komunikasi Shannon Weaver ................................... 187

Gambar 10.4 Model Komunikasi Newcombs .............................................. 188

Gambar 10.5 Model Komunikasi Westley dan MacLean ............................. 188

Gambar 10.6 Model Komunikasi De Fleur..................................................... 189

Gambar 10.7 Model Komunikasi Gerbner ................................................. $\quad 190$

Gambar 10.8 Model Komunikasi Riley dan Riley ...................................... 191

Gambar 10.9 Model Komunikasi Maletzke................................................ 192

Gambar 10.10 Model Komunikasi HUB ....................................................... 192 


\section{DAFTAR TABEL}

Halaman

Tabel 4.1 Titik Singgung Antara Teori Organisasi dan Budaya.............. 55

Tabel 4.2 Elemen Budaya Organisasi menurut Berbagai Sumber........... 62

Tabel $4.3 \quad$ Tahap Perencanaan Kotter .................................................... $\quad 68$

Tabel 4.4 Strategi untuk Mengatasi Resistensi Perubahan...................... 71

Tabel 6.1 Cara tradisional dan modern dalam mengendalikan keputusan terprogram dan tidak terprogram............................................ $\quad 99$

Tabel 6.2 Nilai yang diharapkan untuk lokasi toko pada tiap kemungkinan lokasi ........................................................... $\quad 104$

$\begin{array}{lll}\text { Tabel 8.1 Perbedaan insentif berbagi manfaat dan berbagai keuntungan. } & 148\end{array}$ 


\section{DAFTAR PUSTAKA}

Agung. Stoner, James \& A.F. Freeman, 1996. Manajemen. Jakarta: Prenhallindo. Vinzant, Janet C., dan Vinzant, Douglas H. 1999. Strategic Management Spin-offs of The Deming Approach. Journal of Management History, Vol. 5 No. 8, 1999, pp. 516-531.(C) MCB University Press, 1355-252X.

Amanah, D. 2011. Pengantar Manajemen. Medan: Penerbit Unimed.

Anderson Gordon, 1992. Selection dalam Brian, Towers ed, The Handbook Of Human Resource Management, Oxford, Blackweel Publisher.

Armstrong Michael, 1998. Performance Management, London, Kogan page limited.

Arni Muhammad. 1995. Komunikasi Organisasi. Bumi Aksara, Jakarta.

A.W.Wijaya. 2000. Ilmu Komunikasi Pengantar Studi. Jakarta: Rineka Cipta.

Bacal Robert, 1999, Performance Management, New York, Mc.Graw. Hill.

Barrett, Richard, 2003. Vocational Business: Training, Developing and Motivating People- Business \& Economics-halaman 51.

Bartol, Kathryn M. \& David C. Martin, 1994, Management, McGraw-Hill Inc., USA.

Bouckaert, Geert, dan Dooren, Wouter van (Diedit oleh Tony Bovaird dan Elke Löffler). 2003. Performance Measurement and Management in Public Sector Organization (dalam buku Public Management and Governance). New York. Routledge.

Bovaird, Tony (Diedit oleh Tony Bovaird dan Elke Löffler) . 2003. Strategic Management in Public Sector Organizations (dalam buku Public Management and Governance). New York. Routledge.

Bruijn, Hans de. 2002. Performance Measurement in The Public Sector: Strategies to Cope with The Risks of Performance Measurement. The International Journal of Public Sector Management. (C) MCB Up Limited,0951-3558 DOI 10.11081 0951355021044

Budi Paramita, 1977, Organizational Structure in Indonesia, Lembaga Penerbit Fakultas Ekonomi Universitas Indonesia, Jakarta.

Flippo Edwin B, 1994. Personal Management (6 th edition), New York: Mc. Graw Hill, Company.

Ghobadian, Abby, dan Ashworth, John. 1994. Performance Measurement in Local Government-Concept and Practice. International Journal of Operations \& Production Management, vol. 14 No. 5, 1994, pp. 35-51. (C) MCB University Press, 0144-3577.

Goldhaber, Gerald M. 1990. Organizational Communication. Wm. C. Brown Publisher, Dubuque.

Greiling, Dorothea. 2005. Performance Measurement in the Public Sector: the German experience. International Journal of Productivity and Performance Management Vol. 54 No. 7, 2005 pp. 551-567q Emerald Group Publishing Limited 1741-0401 DOI $0.1108 / 17410400510622223$

Griffin, R. W. 2006. Business, 8th Edition. New Jersey: Prentice Hall.

Griffin, R. W. 2013. Fundamentals of Management, 7th Edition. South-Western College Pub.

Guest David E, 1987. Human Resource Management And Industrial Relation, Journal Of Management Studies, 24: 5, September.

Hani Handoko T. 2003. Manajemen edisi 2. Yogyakarta: BPFE. 
Harahap, D. A., Agustini, F., Amanah, D., \& Riza, S. 2017. The Comparison of Work Motivation between Employees and Staffs Based On Two Factor Theory of Motivation in PT PP London Sumatra Indonesia At Bah Lias Research Perdagangan North Sumatera Indonesia. International Journal of Engineering and Management Invention, 2 (1), 187-192.

Hasibuan Malayu, 1997. Manajemem Sumber Daya Manusia, Jakarta: Gunung Agung. Https://pakarkomunikasi.com/fungsi-komunikasi-dalam-organisasi.

Jiwanto, Gunawan., 1985. Komunikasi dalam Organisasi, Pusat Pengembangan Manajemen \& Andi Offset, Yogyakrta.

Kotler, Philip, 2000, Marketing Management, The Millenium Edition, Prentice-Hall, Inc., New Jersey.

Kouzmin, Alexander, et. al. 1999. Benchmarking and Performance Measurement in Public Sectors Towards Learning for Agency Effectiveness. The International Journal of Public Sector Management, Vol. 12 No. 2, pp. 121-144. (C) MCB University Press, 0951-3558

MacAdam, et. al. 2002. Sustaining Quality in the UK Public Sector. Quality Measurements Framework. International Journal of Quality \& Reliability Management. Vol. 19. No. 5,2002. pp. 581-595. (C) MCB Up Limited, 0265-671X DOI 10. 1108102656710210427548.

Moullin, Max. 2004. Eight Essentials of Performance Measurement. International Journal of Health Care Quality Assurance. Volume 17 . Number 3. pp. 110-112 () Emerald Group Publishing Limited. ISSN 0952-6862 DOI 1108/095268604 10532748.

Mulyana, D. 2000. Human Communication. Bandung: PT Remaja Rosdakarya.

Neely, Andi. 2004. The Challenges of Performance Measurement. Management Decision (2004) Vol. 42 No. 8, pp. 1017-1023. (C) Emerald Group Publishing Limited 0025- 747 DOI 10.1108/00251740410555515.

Pace R. Wayne and Faules, Don F, 2000. Komunikasi Organisasi, Bandung: Rosda.

Priyono, 2007. Pengantar Manajemen, Sidoarjo: Penerbit Zifatama Publisher.

Randall S Schuller, Susan E. Jackson, 1997. Manajemem Sumber Daya Manusia Abad 21, Jakarta: Erlangga.

Robbins, Stephen P. 2003. Manajemen. Edisi Indonesia. Jakarta: PT. Indeks Kelompok Gramedia.

Robbins, Stephen P. 2006. Perilaku Organisasi. Jilid Kesatu. Jakarta: Prenhalindo Persada.

Rogers, Everett M. 1976. Communication and Development: Critical Perspectives. SAGE Publications.

Salusu, J. 2006. Pengambilan Keputusan Stratejik untuk Organisasi Publik dan Organisasi Nonprofit. Jakarta: Grasindo.

Schuler Randall S, Dowling, Peter J Smart, John P \& Huber, Vandral, 1992. Human Resource Management in Australia, Anatarmon-wsw, Harper Educational Publisher.

Siagian Sondang P, 1998. Manajemem Sumber Daya Manusia, Jakarta: Bumi Aksara.

Sikula Andrew, 1981. Personal Administration and Human Resource Management, New York: A Wiley Trans Edition By John Willey \& Sons, Inc

Silalahi, Ulbert. 1996. Pemahaman Praktis : Asas-asas Manajemen. Bandung: CV. Mandar Maju. 
Smircich, L. (1983). Concepts of Culture and Organizational Analysis. Administrative Science Quarterly, 28 (3).

Sule, Ernie Trisnawati, Kurniawan Saefulloh. 2005. Pengantar Manajemen. Jakarta: Prenada Media Group.

Uchjana Effendi, Onong., 1992. Ilmu Komunikasi, Teori dan Praktek, Bandung: Remaja Rosdakarya.

Umar, Husein. 2002. Metode Riset Komunikasi Organisasi (Sebuah Pendekatan Kuantitatif). Jakarta: PT. Gramedia Pustaka Utama.

Wilson, Alan. 2000. The Use of Performance Information in the Management of Service Delivery. Marketing Intelligence \& Planning 18/3 [2000] 127-134 (C) MCB University Press. 